International Journal of Trend in Scientific Research and Development (IJTSRD) International Open Access Journal |www.ijtsrd.com

No: 2456 - 6470 |Conference Issue - ICDEBI-2018

INTERNATIONAL CONFERENCE ON DIGITAL ECONOMY AND

ITS IMPACT ON BUSINESS AND INDUSTRY

Organised By: V. P. Institute of Management Studies \& Research, Sangli

\title{
Impact of Ebanking in Rural India with Special Reference to Selected Taluk in Erode District, Tamil Nadu
}

\author{
Dr. Nithya Ramachandran \\ Faculty Business Studies, IBRA College of Technology, Sultanate of Oman
}

\begin{abstract}
The banking system is the back bone of any economy system. The strength of financial system depends on sound banking system. Due to lack of awareness among people, even after decades of emergence of banking industry it was not used effectively. In recent times the Indian population has started availing the facilities of the banks. E banking trend is spreading at a faster rate in all the countries. Banks provide internet banking services to its national and international customers. The study is an attempt to measure to the awareness of $\mathrm{E}$ banking / system introduced by banks in rural areas. The study was conducted in Modakurachi village of Erode district of Tamilnadu. Theprimary data was obtainedusing awell- designed questionnaire. The questionnaire was equipped with questions relating to demographic factors, level of awareness on E- banking among the respondents and factors influencing to choose $\mathrm{E}_{\text {- }}$ banking.Forthisstudy,250respondents

irrespectiveoftheirtypeofbankaccount, occupation,age andeducationallevelhavebeenselectedrandomlyas a sampleofthedataanalysis. The banks available in the study area are Canara bank, Indian overseas bank, State bank of India and City union bank. Out of 250 respondents, $55.2 \%$ were holding account in public sector banks. The awareness level on E banking was $68.8 \%$. The accounts of $34.8 \%$ of the respondents were not self- maintained. Majority of the respondents were familiar with internet browsing but were reluctant to use facilities like bill payments and fund transfer, etc. The reasons for not using $\mathrm{E}$ banking facilities were found to be that there are no regular banking activities among the customers, lack of high speed internet and the bank website is not user friendly. The banks can consider changing the website

bilingual (English\& regional language). The errors and frauds happening in internet banking should be reduced to motivate the users of internet banking facilities.

KEYWORD: E banking,

\section{INTRODUCTION}

The banking system is the back bone of an economy. The strength of financial system depends on sound banking system. An effective and sound banking system uses its savings in productive sectors and also meets the obligations of the depositors. In the chariot of economic progress, banking is the kingpin. Due to lack of awareness among people, even after decades of emergence of banking industry it was not used effectively. In recent times the Indian population has started availing the facilities of the banks. E banking trend is spreading at a faster rate in all the countries. Banks provide internet banking services to its national and international customers. Internet banking is very cost effective and speedy processing method.

The process of using computers/mobiles as a medium for banking services is known as internet banking. The customers access their account information through a web-based service. The bank website permits the customer to $\log$ in and do any kind of transactions, but such $\log$ in must be authorized by the banking system through personal identification number (PIN). Due to advancement in technology, banks have come forward to accept the change. The banks use electronic and telecommunication networks to provide a huge range of value added services to its customers. Internetplaysvital
\end{abstract}


rolebetweenbanksandcustomerstoreceiveanddeliverinf ormation, thisform ofbankingis describedasInternetbanking(ReserveBankofIndia,2001 ).

\section{DefiningElectronicbanking}

A banking system that allows customers to perform bank transactions through internet, Transactions like account transfers, balance enquiries, bill payments, etc. are done through this system. Some banking offer services like loan, credit card applications forms through this system. The banking activities can be classified as transactional and non- transactional activities.Electronic transfer of funds, Payment of bills, Loan $\mid \&$ credit card application

Investment products are few of transactional activities and Viewing of account balance, Viewing of previous transactions, Downloading of Bank statement, Ordering Check book, mobile banking and internet banking application forms are few of nontransactional activities.

\section{RESEARCH SIGNIFICANCE}

Thebanking industry, being backbone of Indian economy is undergoing vast changes. Advancement in information technology, global business development and demand from customers has paved way for changes in the banking scenario. The study is a bird's eye view of E-banking in rural India. After demonetization, remonetization has taken place. Due to the advancement of technology, banking sector looks ahead for more paperless transactions. This was considered as right time to study about the usage of electronic banking system in rural India. The study aims to understand the awareness about the electronic banking system in rural India. The study was conducted in Modakurachitaluk of Erode district, Tamil Nadu, South India.

\section{STATAEMENT OF THE PROBLEM}

According to census 2011, out of 121 crore Indians, 83.3 crore live in rural areas while 37.7 crore live in urban areas. The total population of Tamil Nadu is 7.21 crores out of which $51.6 \%$ live in rural areas and $48.4 \%$ live in urban areas.(India Population Census, 2011)

\section{Rural Urban Tamil Nadu}

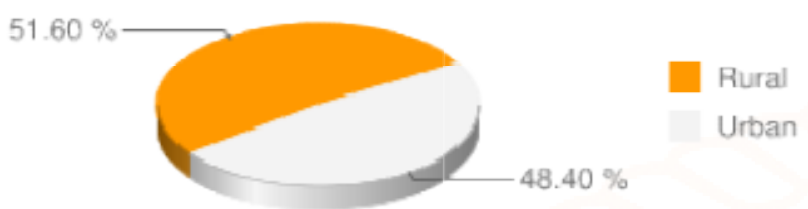

The study area is Erode district, which contributes around $3.12 \%$ of the total population of Tamil Nadu. Around $51.43 \%$ of the Erode district population are staying in urban areas of the district while $48.57 \%$ stay in rural areas.

\section{Rural Urban Erocle}

The around $70 \%$ of the total Indian population lives in rural areas. So the study on this topic in rural areas was found to be of high importance. The study aimed to understand the awareness of electronic banking facilities available to the people in rural areas. This would be an eye opener to the people also to move forward to an electronic transaction mode from paper and manual mode of transactions.

\section{Population outline:}

The study has been conducted in Modakurachitaluk of Erode district. Modakurachi is a town panchayat. The taluk is divided into 15 wards. The population of the taluk with 3076 families is 9907 . The numbers of male are 4931 and female are 4976. The sex ratio is 1009 and the literacy rate is $72.4 \%$. (Statistics, 2014-15)

\begin{tabular}{|c|c|c|c|}
\hline Data & Male & Female & Total \\
\hline Population & 4931 & 4976 & 9907 \\
\hline Literacy & $81.25 \%$ & $63.66 \%$ & $72.36 \%$ \\
\hline \multicolumn{4}{|c|}{ Data from Census report, 2011}
\end{tabular}

\section{OBJECTIVES OF THE STUDY}

The following are set objectives of the study.

$>$ To study the impact of demographic factors on the awareness level of respondents about E- Banking.

$>$ To find and analyse the factors influencing use of E- banking.

$>$ To find out the opinion of the respondents regarding the various problems of phone / mobile banking. 
International Journal of Trend in Scientific Research and Development (IJTSRD) ISSN: 2456-6470 | IF: 4.101

\section{REASEACRCH METHODOLOGY \\ Scope of the study}

Thisstudyisademographical study,basedon usageofEBanking servicesbyvariousclasses ofpeople irrespectiveofoccupation,age, sexandliteracy. The research work was undertaken by getting the research questionnaires filled by the respondents.

\section{Methodology}

Thisstudyis basedonprimarydata collected fromthe respondents. The data was analysed with the help of simplestatisticaltools likepercentage, average,t-test, etc.

\section{Data collection and sampling method}

Theprimary data wasobtainedusing awelldesignedquestionnaire.Thequestionnaire was equipped with questions relating to demographic factors, level of awareness on E- banking among the respondents and factors influencing to choose Ebanking.Forthisstudy,250respondents

irrespectiveoftheirtypeofbankaccount, occupation,age andeducationallevelhavebeenselectedandomlyasa sampleofthedataanalysis. The banks available in the study area are Canara bank, Indian overseas bank, State bank of India and City union bank.

\section{Limitations of the study}

$>$ The study area is confined only to Modakurachitaluk, Erode district, Tamil Nadu.

$>$ The sample size of the research is only 250 respondents.

$>$ The data collection was done during the month of January, 2018. The attitude of the customer may change in the future.

$>$ The study considers bank transactions done using internet and mobile only as the e banking activities.

\section{ANALYSIS AND INTERPRETATION}

The following table shows the analysis of data collected with related interpretation detailing the results of the analysis.

Table 1: Gender of the respondents

\begin{tabular}{|c|c|c|}
\hline Gender & No. OfRespondents & Percentage (\%) \\
\hline Male & 132 & 52.8 \\
\hline Female & 118 & 47.2 \\
\hline Total & 250 & 100 \\
\hline
\end{tabular}

The above table shows that $52.8 \%$ of the respondents are male and $47.2 \%$ of the respondents are female.

Table 2: Age of the respondents

\begin{tabular}{|l|l|l|} 
Age & No. of & Percentage $\%$ \\
\hline
\end{tabular}

\begin{tabular}{|c|c|c|}
\hline & $\begin{array}{c}\text { Responde } \\
\text { nts }\end{array}$ & \\
\hline Below 20 Years & 52 & 20.8 \\
\hline 21 to 30 Years & 124 & 49.6 \\
\hline 31 to 40 years & 41 & 16.4 \\
\hline Above 40 Years & 33 & 13.2 \\
\hline Total & 250 & 100 \\
\hline
\end{tabular}

The above table clearly states that the maximum percentages of the respondents are in the age group of 21 to 30 years. As the study is related to e-banking, this age group are the maximum users.

Table 3: Educational Qualification of the respondents

\begin{tabular}{|c|c|c|}
\hline $\begin{array}{c}\text { EducationalQualificat } \\
\text { ion }\end{array}$ & $\begin{array}{c}\text { No.of } \\
\text { Responden } \\
\text { ts }\end{array}$ & $\begin{array}{c}\text { Percenta } \\
\text { ge (\%) }\end{array}$ \\
\hline BelowHSC & 40 & 16 \\
\hline HSC & 38 & 15.2 \\
\hline UnderGraduate & 60 & 24 \\
\hline PostGraduate & 62 & 24.8 \\
\hline Professional & 50 & 20 \\
\hline il J OulTotal & 250 & 100 \\
\hline
\end{tabular}

From the data collected from the respondents regarding their educational qualification, it shows that higher percentages $(24.8 \%)$ of the respondents are educated upto post graduate level.

Table 4: Occupation of the respondents

\begin{tabular}{|c|c|c|}
\hline Occupation & $\begin{array}{c}\text { No.of } \\
\text { Respondents }\end{array}$ & $\begin{array}{c}\text { Percentage } \\
(\%)\end{array}$ \\
\hline Student & 43 & 17.2 \\
\hline Employed & 60 & 24 \\
\hline Self - Employed & 74 & 29.6 \\
\hline House wife & 48 & 19.2 \\
\hline Others & 25 & 10 \\
\hline Total & 250 & 100 \\
\hline
\end{tabular}

From the above table it clearly shows that $29.6 \%$ of the respondents are self - employed and $24 \%$ of the respondents are employed.

Table 5: Type of bank where account is maintained by the respondents

\begin{tabular}{|c|c|c|}
\hline $\begin{array}{c}\text { Type of } \\
\text { bank }\end{array}$ & No.OfRespondents & $\begin{array}{c}\text { Percentage } \\
(\%)\end{array}$ \\
\hline Public sector & 138 & 55.2 \\
\hline Private & 112 & 44.8 \\
\hline
\end{tabular}


International Journal of Trend in Scientific Research and Development (IJTSRD) ISSN: 2456-6470 | IF: 4.101

\begin{tabular}{|c|c|c|}
\hline sector & & \\
\hline Total & 250 & 100 \\
\hline
\end{tabular}

\begin{tabular}{|c|c|c|}
\hline Unaware & 15 & 6 \\
\hline Totally unaware & 33 & 13.2 \\
\hline Total & 250 & 100 \\
\hline
\end{tabular}

The table shows the type of bank where the respondents are maintaining their accounts. Higher percentage $(55.2 \%)$ of the respondents are having their account with the public sector banks and $44.8 \%$ of the respondents are having their account with the private sector banks.

Table 6: Reason for visiting the bank

\begin{tabular}{|c|c|c|}
\hline $\begin{array}{c}\text { Reason for } \\
\text { visiting bank }\end{array}$ & $\begin{array}{c}\text { No.of } \\
\text { Respondents }\end{array}$ & $\begin{array}{c}\text { Percentage } \\
(\%)\end{array}$ \\
\hline Deposit & 105 & 42 \\
\hline Withdraw & 52 & 20.8 \\
\hline Avail Services & 44 & 17.6 \\
\hline Enquiry & 31 & 12.4 \\
\hline Others & 18 & 7.2 \\
\hline Total & 250 & 100 \\
\hline
\end{tabular}

Table 8 is the awareness of E-Banking services provided by their bank. The results shows that $48 \%$ of the respondents are fully aware of the services provided by their respected banks. Around 20.8\% of the respondents are aware of the E-Banking services. The study reveals that around $13.2 \%$ of the respondents are totally unaware of the E-Banking services.

Table 9: Reasons for lack of awareness

\begin{tabular}{|c|c|c|}
\hline $\begin{array}{c}\text { Reasons for lack of } \\
\text { awareness }\end{array}$ & $\begin{array}{c}\text { No.OfRespon } \\
\text { dents }\end{array}$ & $\begin{array}{c}\text { Percenta } \\
\text { ge }(\%)\end{array}$ \\
\hline $\begin{array}{c}\text { Education } \\
\text { Lack of facility }\end{array}$ & 78 & 31.2 \\
\hline $\begin{array}{c}\text { Account not self- } \\
\text { maintained }\end{array}$ & 85 & 34 \\
\hline Total & 250 & 34.8 \\
\hline \multicolumn{2}{|c|}{} \\
\hline
\end{tabular}

bank by the respondents. Majority $(42 \%)$ of the respondents visit the bank for the purpose the depositing their amount in the bank. Around $20.8 \%$ of the respondents are visiting the bank for the purpose of withdrawal.

Table 7: Awareness of E- banking facility

\begin{tabular}{|c|c|c|}
\hline $\begin{array}{c}\text { Awareness of } \\
\text { E-Banking } \\
\text { facility }\end{array}$ & No.OfRespondents & $\begin{array}{c}\text { Percentage } \\
(\%)\end{array}$ \\
\hline Yes & 172 & 68.8 \\
\hline No & 78 & 31.2 \\
\hline Total & 250 & 100 \\
\hline
\end{tabular}

The above table shows that the $68.8 \%$ of the respondents are aware of the E-Banking facility provided by their banks and $31.2 \%$ of the respondents are not aware of the E- Banking facility provided by their bank.

Table 8: Awareness level of E- banking services

\begin{tabular}{|c|c|c|}
\hline $\begin{array}{c}\text { Awareness level } \\
\text { oftE-Banking } \\
\text { services }\end{array}$ & $\begin{array}{c}\text { No.of } \\
\text { Respondents }\end{array}$ & $\begin{array}{c}\text { Percentag } \\
\text { e (\%) }\end{array}$ \\
\hline Fully aware & 120 & 48 \\
\hline Aware & 52 & 20.8 \\
\hline May be & 30 & 12 \\
\hline
\end{tabular}

The above table shows the reasons for the lack of awareness on E-Banking among the respondents. The reason with higher percentage (34.8) is that the account is not self- maintained.

Table 10: Reason for using the E-Banking facility

\begin{tabular}{|c|c|c|}
\hline $\begin{array}{c}\text { Reasons for } \\
\text { using E- } \\
\text { Banking } \\
\text { facility }\end{array}$ & No.OfRespondents & $\begin{array}{c}\text { Percentage } \\
(\%)\end{array}$ \\
\hline Easy & 75 & 30 \\
\hline $\begin{array}{c}\text { Safe and } \\
\text { secure }\end{array}$ & 52 & 20.8 \\
\hline $\begin{array}{c}\text { Low } \\
\text { transaction } \\
\text { charges }\end{array}$ & 45 & 18 \\
\hline Not used & 78 & 31.2 \\
\hline Total & 250 & 100 \\
\hline
\end{tabular}

Table 10 states the reasons for using the E- Banking facility by the respondents. ROUND $31.2 \%$ of the respondents have not used the facility and $30 \%$ of the respondents used the facility as it is easy and $18 \%$ of the respondents are using the facility because of low transaction charges.

Table 11: Usage of E-Banking facility based on familiarity

Usage of e- banking

facility based on

familiarity
Strongly

familiar
Familiar Neutral
Very less

familiarity
Completely not

familiar

Total 
International Journal of Trend in Scientific Research and Development (IJTSRD) ISSN: 2456-6470 | IF: 4.101

\begin{tabular}{|c|c|c|c|c|c|c|}
\hline Internet browsing & 120 & 52 & 30 & 40 & 8 & 250 \\
\hline visiting bank website & 112 & 46 & 29 & 35 & 28 & 250 \\
\hline $\begin{array}{l}\text { Access of online banking } \\
\text { information }\end{array}$ & 108 & 44 & 25 & 42 & 31 & 250 \\
\hline Viewing account statements & 115 & 50 & 30 & 25 & 30 & 250 \\
\hline Transfer funds & 110 & 41 & 22 & 28 & 49 & 250 \\
\hline Make bill payments & 115 & 52 & 26 & 27 & 30 & 250 \\
\hline $\begin{array}{l}\text { Avail banking facilities } \\
\text { online }\end{array}$ & 100 & 48 & 22 & 35 & 45 & 250 \\
\hline
\end{tabular}

The above table shows the usage of E-Banking facility based on the familiarity of the facility. Majority of the respondents (120 respondents) are familiar with internet browsing which is makes them familiar with the E-Banking facility.

Table 12: Reasons for not using E-Banking facility

\begin{tabular}{|c|c|c|c|c|c|c|}
\hline \multirow{2}{*}{$\begin{array}{l}\text { Reasons for } \\
\text { not using e- } \\
\text { banking } \\
\text { facility }\end{array}$} & \multicolumn{5}{|c|}{ Rank } & \multirow{2}{*}{$\begin{array}{l}\text { Tot } \\
\text { al }\end{array}$} \\
\hline & 1 & 2 & 3 & 4 & 5 & \\
\hline $\begin{array}{ll}\text { Lack of } \\
\text { enough } \\
\text { knowledge }\end{array}$ & 49 & 60 & 72 & 25 & 44 & 250 \\
\hline No computer & 20 & 32 & 35 & 43 & 120 & 250 \\
\hline $\begin{array}{l}\text { Lack of high } \\
\text { speed internet }\end{array}$ & 95 & 74 & 49 & 22 & 10 & 250 \\
\hline $\begin{array}{l}\text { Non-user } \\
\text { friendly bank } \\
\text { website }\end{array}$ & 64 & 44 & & 72 & 30 & $\begin{array}{l}250 \\
\text { eve }\end{array}$ \\
\hline $\begin{array}{l}\text { No regular } \\
\text { banking } \\
\text { activities }\end{array}$ & 22 & 40 & 54 & 88 & 46 & 250 \\
\hline Total & 250 & 250 & 250 & 250 & 250 & 8 \\
\hline
\end{tabular}

The above table shows that the reasons for not using E-Banking facility. Around 95 respondents say that lack of high speed internet facility is the reason for not using the facility.

\section{CONCLUSION}

The banking industry being back bone for economic development is undergoing vast advancement through technology. But does this technology advancement in banking sector reached the rural areas, The customers in rural areas are maximum aware of $\mathrm{E}$ banking services but are reluctant to use it due to pitfalls in the system. The customers will start to use the services of the banks if the bank website is made user friendly and fraud free. There were many studies made in the past on various aspects related to E banking services. The services provided in rural banks can be enhanced like that of urban area banks. The study reveals that knowledge of $E$ banking, no regular banking activities and lack of high speed internet are the drawbacks of $\mathrm{E}$ banking in rural areas.

\section{REFERENCES}

1. 2011, C. (2011). District wise census, 2011.

2. (2011). India Population Census.

3. Statistics, D. D. (2014-15). District statstical handbook. 